"I see great promise for the improvement of our schools in the adoption of the Management Team idea. But it is not an idea that can be evaluated in isolation. More specifically, how educational personnel are grouped for purposes of professional negotiations will be a substantially influential factor in determining the feasibility and effectiveness of such a team."

\title{
The Management Team and Negotiations
}

LESTER W. ANDERSON

\begin{abstract}
C URRENTLY, school administrators around the country are becoming increasingly interested in the possibilities inherent in what is called the Management Team Concept. As one would expect, some of the discussion focuses on the appropriate composition of such a team. We are in the process of defining a new concept in educational administration-or is it, rather, an old concept in a new setting?-and there will have to be many exchanges of ideas and experiences before a single and generally accepted definition can be arrived at. But, I predict, in the course of these interchanges in search of a definition we shall also have valuable opportunities to reexamine a number of our favorite administrative convictions and standard practices.

In the meantime, however, I believe the words "management team" will suggest to most readers a pattern of close working relationships among and between administrators at all levels in a school system which involves something more than casual con-

Lester $W$. Anderson is a professor of educational administration at the University of Michigan. This article is a slightly modified version of one that was published originally in the Michigan Journal of Secondary Education.
\end{abstract}


tacts. This general, even though not quite precise, idea of what the Management Team concept is all about is adequate for the context in which I now want to consider it.

As you will readily infer, I see great promise for the improvement of our schools in the adoption of the management team idea. But it is not an idea that can be evaluated in isolation. More specificially, how educational personnel are organized or grouped for purposes of professional negotiations will be a substantially influential factor in determining the feasibility and effectiveness of such a team. Conversely, the existence of an efficient administrative team will help a school system select appropriate negotiations groupings. I propose now to examine a few aspects of this interrelationship.

\section{Disruption by Collective Bargaining}

The widespread adoption by teachers of collective bargaining as a way of life certainly has stirred up controversy in administrative circles, and it is probable that most principals are going to have to live with their mixed emotions for still a few more years. When teachers decided to bargain directly with boards of education on a collective basis, they disrupted one traditional role of school administrators-that of being the official spokesmen for the interests of teachers, particularly in the areas of salaries and conditions of work. By their actions, teachers rejected administrators as their representatives to the board of education. It was not by choice of the principals-nor of the superintendents-that principals were by-passed by teachers in these matters. Consequently, administrators have reacted defensively, expressing dismay over the fact that teachers no longer want them as their representative to the board. Administrators who had assumed a paternalistic role with teachers found it hard to accept the idea that teachers would reject them "after all they had done for them in the past."

As a result of the end-run made by teachers and the generally defensive attitude of administrators, confusion was created among administrators with respect to their authority and the roles they could or must play. Board members and administrators had not generally anticipated their changing role under collective bargaining, and it was too late to do it while bargaining was in session. A carefully defined logic for their behavior and responsi- 
bilities under the new conditions was missing. They found themselves playing a new ball game without having learned the rules of the game before it started, and they were opposed by an opponent who knew the rules and who had taken the initiative. There is little wonder that many administrators and members of boards of education found themselves upset and frustrated with the entire operation. It could have been predicted also that mistakes would be made in judgment, behavior, and roles played. Correcting some of the errors made during the early rounds of collective bargaining has been a major motivating force behind the discussions of the Management Team concept.

Although there is a common concern over the consequences of collective bargaining in changing the environment in which school administration is practiced, perceptions of the errors and problems appear to be slightly different, depending upon the position of the person within the school organization. Let us, then, describe the problem as it might be interpreted through the eyes of the principal, the superintendent of schools, and members of the board of education.

\section{The Principal's View}

During the first rounds of collective bargaining, the principal was a lonely man. It was as if he had been placed in an isolation chamber. In states where he was forbidden by law to serve with the teachers in formulating their demands for bargaining, feelings of rejection by the principal were to be expected because, of all the administrators in a school system, the principal traditionally had been the closest ally of the teachers. The principal is where the action is and provides a buffer between teachers, other administrators, and the board of education. It is the principal who talks with teachers daily; he is usually the first person involved in trying to resolve their teaching problems. But he also is the first to be charged with a grievance if the contract is not administered according to the expectations of the teachers. Historically, the principal has viewed his role as being the instructional leader of his teachers. And now, he was unwanted by the same people with whom he works daily.

To make the principal's feelings of isolation even more complete, boards of education and superintendents frequently ignored him during the bargaining sessions. When a caucus was 
held to evaluate proposals by teachers and to prepare counter proposals by the board, the principal frequently was not invited to participate. Apparently, it never occurred to the superintendent and board of education that principals were an important part of the management team, in spite of the fact the principal administers many of the contract provisions. Opportunities for the principal to use his expertise and to influence policy decisions affecting his welfare were missing from the collective bargaining process. As a result, concessions were made in bargaining which placed serious limitations on effective administration by the principal.

In many instances, communication was in one direction only, that is, from the board and superintendent down to the principal. Principals are saying, "We must be involved in the process of policy formulation and decision making when the policies affect our professional responsibilities." This is such a fundamental viewpoint within a participatory democracy that one wonders why it has been neglected or implemented so ineffectively in the present instance.

An essential ingredient in the Management Team concept is a commitment to involving people in the process of policy formulation, especially when the policies are so directly related to their duties as is the case in the relationship of collective bargaining to the role of the principal. There is no quarrel with the idea that determination of policy must remain as the exclusive prerogative of the board of education; and the legislative responsibility rightfully belongs with the board. But it is equally important that all administrators have the opportunity to influence legislative decisions. Participation in policy formulation by principals should be considered as a right, not a concession to be granted or removed arbitrarily by the board or superintendent.

It is unlikely that the power of principals will remain isolated in school affairs. Too much is at stake. Their administrative effectiveness, leadership, and status within the community and school system have been threatened and, to the principal, these are vital factors in his professional life.

Assuming an acceptance of the viewpoint that principals should participate in policy formulation, one is confronted with a structural issue. Although a great deal of participation in decision making is accomplished through informal discussions among 
administrators, there is no assurance of participation by all administrators without some plan of formal organization designed to assure participation in the communication network. Thinking of the Management Team operation as only informal communication between administrators, although an important ingredient in the concept, is entirely inadequate in fulfilling the expectations of principals.

\section{What Can Principals Do?}

What are the alternatives? Three occur to me. One is to organize a separate bargaining unit for principals and demand a voice in policy formulation through collective bargaining procedures in much the same manner as that practiced by teachers. There is no doubt but what the use of this approach will force recognition of principals in the decision making process. Advocates of this alternative suggest that principals need to protect their own interests from a position of strength inherent in the collective bargaining procedure. Critics of this position claim that the Management Team concept is incompatible with such an approach because it places principals in an adversary role with the superintendent and the board of education.

A second alternative is to adopt an internal structure within the school system which will provide representation of all administrators in the various administrative units of the school system. Typical of this approach is an arrangement of administrative councils, cabinets, or committees through which policy recommendations are channeled. The size of the school system and the number of administrators involved will determine the various combinations of representative groupings, but the fundamental idea is the same for all, namely, creating channels of communication that will be open for all administrators from top to bottom of the organizational hierarchy. Advocates of this setup stress the idea that management is thereby made cohesive and operates on a basis of mutual trust and a sharing of information by all parties concerned. It is claimed also that the adversary role inherent under formal collective bargaining is reduced in a management team of this type. Critics of this approach claim that its effectiveness is still dependent upon the willingness of the superintendent to respect the representative structure; furthermore, power of decision-making is not assured without the guaranteed procedures a collective bargaining approach provides. 
The third choice is to combine alternatives one and two and have both a formal collective bargaining unit for principals and an internal representative structure. Advocates of this approach say that through collective bargaining it assures principals protection against arbitrary action by the superintendent and board in such matters as conditions of employment and welfare benefits, while at the same time it creates a structure for dealing effectively with management tasks. It is suggested that both relationships can be operated simultaneously where there is a spirit of cooperation by all concerned. Critics of this combination are sure just the opposite is true, for they see these as two mutually exclusive plans.

Before taking a firm position concerning the structure appropriate to a particular school system, an analysis also should be made from other viewpoints besides that of principals.

\section{Board of Education View}

When two adversaries become involved in a confrontation, both sides wish to enter the confrontation with a position of maximum strength; consequently, both sides need to complete a substantial amount of "homework" before the encounter. In preparation for collective bargaining, board of education members are highly dependent upon administrators to supply them with pertinent data and advice concerning the issues to be negotiated. Without such assistance, boards of education would be seriously handicapped in functioning effectively in their legislative role.

There is no doubt in the eyes of the board that the superintendent is their man. To the board of education, he and his line administrators are management, and the board expects them to behave as management with complete loyalty to the board, even during confrontations with teachers. When faced by teachers in a bargaining situation, board members assume that administrators will be on the board's side.

There also is an expectation that once a policy has been established by the board it will be administered effectively, and administrators are a part of the team needed to execute policy decisions. After all, a major purpose of executive officers is to assure efficient and effective management procedures in getting the job done.

It is difficult to argue against the expectation of the board that all administrators will execute established policies. As a matter 
of fact, an administrator probably would be guilty of insubordination if he deliberately violated board policies or if he refused to execute them. A test of this issue is seen clearly in the case of a teacher strike. Although the principal might be sympathetic with the striking teachers, he cannot leave his post and join them on the picket line. To do so would leave his building without a manager, which would be an abdication of one of his major responsibilities, that is, to be in charge of a unit of the school system. In the eyes of the board, leaving a building without an administrator in charge would be a disloyal act. From the board's viewpoint, principals must act as management in such situations, and they must be loyal to the board.

The loyalty issue is a little more complicated, however, especially if loyalty to the board is demanded but is a one way proposition. Loyalty from the board downward to the administrators is also essential for a cooperative working relationship, which is a necessary ingredient in any Management Team concept.

In situations in which the board has not been sensitive to including principals in policy formulation or has not been loyal in support of principals, one can expect to see a structure developed which relies on the adoption of a collective bargaining unit for administrators. On the other hand, it is to be expected that greater reliance on an internal structure without formal collective bargaining would be a reasonable expectation in situations in which the board has been considerate of administrators' views on issues, and in which loyalty flows downward from the board as well as upward to the board.

\section{The Superintendent's View}

The superintendent of schools continues to occupy the pivotal position in the working relationship of the board and other administrators in the system. It is the superintendent who has the final responsibility for administering the policies of the board, and typically the board delegates authority to the superintendent to determine an administrative structure in harmony with his philosophy and his expectations of subordinate administrators.

Although the superintendent has a relatively free hand in determining how the school shall be administered, he is dependent upon other administrators within the system to implement 
whatever plan he chooses to follow. Sharing of authority with principals and other administrators is essential for effective administration of the system. All "line" administrators, including principals, can be thought of as being extensions of the superintendent with appropriate authority designated in keeping with his assigned duties.

From the viewpoint of the superintendent, his effectiveness would be handicapped seriously if he could not depend upon the loyalty of all administrators working under him. As an extension of the office of the superintendent, principals are an integral part of the final authority of the executive branch of the school system. Within the authority structure, principals must be part of the Management Team. It would be a gross inconsistency in administrative theory to delegate responsibilities and authority to an administrator without holding him accountable to the chief executive for his actions.

The question, from the viewpoint of the superintendent, is not whether or not there will be a management team; rather, the issue is how it should be organized and how it will relate to his style of administration. If the superintendent is committed to a philosophy of participatory management, an internal structure will be adopted which is characterized by open communication and mutual dependence among administrators in developing policy recommendations for the board and in planning administrative procedures for the system as a whole. Cooperative working relationships would be expected under such a philosophy, and the Management Team concept would be the natural consequence in this situation.

When the superintendent implements a structure and a philosophy of open communication involving all administrators in the determination of policies, it is unlikely that any additional structure, such as a formal collective bargaining unit, is needed. The Management Team concept would be operating at its best with mutual trust and confidence characteristic of the administrative climate.

It is not difficult to identify situations, however, in which the superintendent of schools is reluctant to delegate authority and assume the position that he is capable of determining administrative policies without the advice and counsel of anyone. Directives are issued and compliance is demanded. 
The superintendent has either rejected the use of an internal structure which provides for cooperative planning among administrators or he has been ineffective in implementing such a structure.

Channels of communication among administrators become one-way propositions, resulting in feelings of antagonism and frustration by those on the receiving end of the communication. It is in situations of this type that sub-administrators seek structural alternatives to assure representation of their viewpoints. When this occurs, formation of a collective bargaining unit becomes very attractive to principals and other administrators below the superintendent.

\section{A Legal Issue}

In addition to taking into account the differing views of men and women with different responsibilities within a school system regarding the Management Team concept, a legal issue exists, as illustrated in a decision by the Michigan Labor Board in the Hillsdale Case concerning the appropriate bargaining unit to represent principals in collective bargaining. The decision of the Michigan Labor Mediation Board was that,

... the nature of the supervision was not sufficient to invoke the prohibition against supervisors being included in units with those employees they supervise. . .

Under this ruling, it appears as though there is an incompatibility between the management team concept and organizing of collective bargaining units which represent both teachers and administrators. An illustration is seen in a situation in which the same organization might represent both the administrators' unit and the teachers' unit for collective bargaining. The question arises immediately as to what action the administrators would take in the case of a strike by the teachers. It appears as though the loyalty of the group to the parent body would make the Management Team concept inconsistent with membership in such a combined collective bargaining unit.

I suggest, therefore, that local administrators interested in developing the Management Team idea should refrain from electing an organization to represent themselves which is also the representative body for teachers. This does not mean local ad- 
ministrators are prohibited from forming a local unit for collective bargaining, nor does it mean that a local unit should not affliate with a regional organization. Rather, I want to call attention to the conflict of interest which appears to be inherent in such a situation.

\section{Final Notes}

The future working relationships among educational administrators are at stake. Decisions made now may establish organizational structures of long duration. It is a challenge to all administrators to analyze the problems confronting them and the alternative solutions available. It is hoped that local decisions will follow a pattern that is supportive of a Management Team based on cooperative working relationships. And in conclusion I want to underline the crucial nature of two factors of the Management Team idea is to be effectively implemented in any context: (1) the acceptance by the superintendent of the viewpoint favoring involving all sub-administrators in administrative planning and in policy formulation; and (2) the adoption of a formal structure which assures a system of open communication with all administrators-top to bottom, bottom to top, and horizontally. 